\title{
ERRATUM
}

\section{Xiaoping Shu \\ Erratum to: Piezothermoelastic responses of piezoelectric composite laminates with weak interfaces}

Published online: 21 April 2010

(C) Springer-Verlag 2010

\section{Erratum to: Acta Mech \\ DOI 10.1007/s00707-010-0296-7}

The original version of this article unfortunately contained a mistake.

The line below Eq. (35) should be:

For simplicity, we take $\bar{R}_{t}=\bar{R}_{n}=\bar{R}_{e}=R . R_{\theta}=10^{7}$. 